\title{
Technology for evaluating the ability of probiotic strains to accumulate copper ions in vitro and in vivo using Bacillus bacteria
}

\author{
Aleksey Sizentsov (D), Elena Salnikova (D), Yaroslav Sizentsov (D), Sergey Peshkov (D), Elena Barysheva(D), \\ Olga Naumenko(i) and Natalia Romanenko(i) \\ Department of Biochemistry and Microbiology, Orenburg State University, 13, Pobedy Prospect, Orenburg, 460018, \\ Russia. \\ Corresponding author: Aleksey Sizentsov, e-mail: asizen@mail.ru \\ Co-authors: ES: salnikova_ev@mail.ru, YS: yasizen@mail.ru, SP: darvin156@mail.ru, EB: baryshevae@mail.ru, \\ ON: prf3@mail.ru, NR: romanenko-na@yandex.ru \\ Received: 14-11-2020, Accepted: 19-05-2021, Published online: 06-07-2021
}

doi: www.doi.org/10.14202/vetworld.2021.1752-1759 How to cite this article: Sizentsov A, Salnikova E, Sizentsov $Y$, Peshkov S, Barysheva E, Naumenko O, Romanenko N (2021) Technology for evaluating the ability of probiotic strains to accumulate copper ions in vitro and in vivo using Bacillus bacteria, Veterinary World, 14(7): 1752-1759.

\begin{abstract}
Background and Aim: Microorganisms of the genus Bacillus comprising probiotics could have an antitoxic effect that is manifested in the active excretion of toxic substances from the body, as well as heavy metals. This study was conducted to assess the effects of copper ions on probiotic strains based on the members of the genus Bacillus in vitro and in vivo.
\end{abstract}

Materials and Methods: The following probiotic preparations were selected for this experiment: "Sporobacterin," "Bactisubtil," and "Vetom-2." Sporobacterin liquid, manufactured by Bakoren LLC, is based on Bacillus subtilis 534. Bactisubtil, manufactured by Marion Merrell Dow, Inc., is based on Bacillus cereus 5832. The first part of the experiment (in vitro) was conducted to assess the influence of copper ions on the growth and bioaccumulating ability of probiotic strains. The second part of the experiment (in vivo) was conducted to assess the influence of copper ions on the body of laboratory animals and to determine the ability of probiotic strains to remove copper ions from the body of laboratory animals. Statistical analysis was performed using Statistical Package for the Social Sciences, calculating the average value $(\mathrm{M})$, standard deviation $(\sigma)$, and standard deviation error $(\mathrm{m}) . \mathrm{p}<0.05$ was used to denote statistical significance.

Results: In the previous studies, we found the presence of pronounced sorption characteristics of representatives of both the intestinal microbiome and probiotic strains based on them. In this study, we have studied the prospects of using physiological and adaptive mechanisms of resistance of transient probiotic strains in the system of correction of the elemental status of the animal body due to excessive intake of copper ions into the body. The advantage of their use is due to not only sorption but also the high levels of elimination of complexes accumulated on the surface. Analyzing the data, we can state the following. The excessive content of copper ions inhibits the activity of all microorganisms, and the presence of $\mathrm{CuSO}_{4}$ in the nutrient medium reduces the exponential growth phase by $6 \mathrm{~h}$ for B. licheniformis. The analysis of data on the bioaccumulating property of the probiotic strains under study shows that B. cereus (part of Bactisubtil) had the most pronounced sorbing effect with the level of accumulation of $23.96 \%$.

Conclusion: We found that probiotic preparations do not affect biochemical indices of blood and biotissues (the muscle and bone tissue, and the cutaneous covering). As a result of determining the ability of Bacillus bacteria comprising the probiotics under this study to accumulate heavy metals by measuring their concentration in the tissues of laboratory animals, the preparations contribute to reducing the toxic effects of copper ions on the body. The cutaneous covering has the greatest accumulation property relative to copper ions. The most effective probiotic under this study in copper ion poisoning was Bactisubtil, and the least effective was Vetom-2.

Keywords: Bacillus, bioaccumulation, copper, in vitro, in vivo, intoxication, ions, probiotics, technology.

\section{Introduction}

Probiotics are living microorganisms that are part of the normal microflora of the human intestinal tract. These are nonpathogenic, beneficial bacteria and yeasts that have resistance to opportunistic or pathogenic microorganisms [1-3]. Metals have the ability of bioaccumulation, which is absent in other elements.

Copyright: Sizentsov, et al. Open Access. This article is distributed under the terms of the Creative Commons Attribution 4.0 International License (http://creativecommons.org/licenses/ by/4.0/), which permits unrestricted use, distribution, and reproduction in any medium, provided you give appropriate credit to the original author(s) and the source, provide a link to the Creative Commons license, and indicate if changes were made. The Creative Commons Public Domain Dedication waiver (http:// creativecommons.org/publicdomain/zero/1.0/) applies to the data made available in this article, unless otherwise stated.
Furthermore, microorganisms could extract and concentrate metals. This ability is also characterized for microorganisms that are included in probiotic preparations, particularly bacteria of the genus Bacillus. In this respect, studying the ability of Bacillus bacteria included in probiotics to accumulate heavy metals is important to assess the effectiveness of probiotics in recovery from poisoning caused by heavy metals. In the future, this can serve as a basis for improving probiotic preparations for treating and preventing intestinal infections while simultaneously removing toxic substances, particularly heavy metals, from the body [4-6].

Copper is one of the most important elements needed for living organisms. It is a vital element 
that is part of many vitamins, hormones, enzymes, and respiratory pigments and involved in metabolic processes and tissue respiration [7]. However, an excessive amount of copper compounds in the body is toxic to humans. Simultaneously, intoxication can be both acquired and hereditary [8]. Note that Bacillus bacteria contained in probiotics are self-eliminating antagonists and could have an antitoxic effect that is manifested in the active excretion of toxic substances, particularly heavy metals, from the body [9].

This study was conducted to assess the effects of copper ions on probiotic strains based on the members of the genus Bacillus in vitro and in vivo.

\section{Materials and Methods}

\section{Ethical approval}

Animals maintenance and procedures during the experiments met the requirements of the instructions and recommendations of Russian regulations (Order of the Ministry of Health of the USSR No. 755 of 12.08.1977) and "The Guide for Care and Use of Laboratory Animals" (National Academy Press, Washington, D.C., 1996).

\section{Study period and location}

The study was conducted in September 2015 at Orenburg State University, Russia.

\section{Probiotic strains}

The following probiotic preparations were selected for our experiment: "Sporobacterin," "Bactisubtil," and "Vetom-2." Sporobacterin liquid, manufactured by Bakoren LLC (Orenburg, Russia), is based on Bacillus subtilis 534. Bactisubtil, manufactured by Marion Merrel Dow, Inc. (France), is based on Bacillus cereus 5832. Furthermore, Vetom-2 is a bi-preparation manufactured by LLC SPC Issledovatelsky Tcentr (Novosibirsk, Russia) and contains immobilized, dried spore biomass of B. subtilis 7048 and Bacillus licheniformis 7038. Copper ions (copper sulfate (II)) were used as the toxicant.

\section{In vitro methods}

The first part of the experiment (in vitro) was conducted to assess the influence of copper ions on the growth and bioaccumulating ability of the probiotic strains under study. The following methods were chosen for the in vitro analysis: The serial dilution method, photoelectrocolorimetric method, and atomic-absorption method. Concentrations of the metal salt in test tubes where heavy growth was recorded in the form of flake-shaped sediments (compared with the microorganism growth control) were considered as not affecting the growth of the microorganisms under study. A dilution characterized by a meager increase in the growth of the bacteria under study was marked as the minimum inhibitory concentration (MIC). This technique is described in more detail in the article [10]. The growth dynamics of probiotic cultures were assessed using the optical density of the suspension. The optical density of the bacterial suspensions was measured at a wavelength of $600 \mathrm{~nm}$, in a pan with an optical path length of $10 \mathrm{~mm}$ (FEK KFK-3, Russia). The cell concentration in the medium is directly proportional to the value of light diffusion. The optical density of the bacterial suspension was measured at 3-h intervals. The onset of the stationary growth phase was considered three roughly equal values. Thermostatization was held at $37^{\circ} \mathrm{C}$. The samples were initially processed according to the standard analysis method using an atomic-adsorption photometer to determine the amount of accumulated metal. A type MGA-915 (МГA-915) device was used as the atomic-absorption spectrophotometer. The effects of metals on the morphology of microbial cells were investigated using atomic-force microscopy. The bacteria were cultivated in a liquid nutrient medium with metal salts for $36 \mathrm{~h}$ at $37^{\circ} \mathrm{C}$ and then were laundered. The concentration of metal salts in which microorganisms were cultured was chosen based on the MIC. The samples were scanned on a CMM-2000 atomic-force microscope (CJSC "PROTON-MIET," Russia) using the contact mode. The standard software of the microscope was used to analyze the derived images.

\section{In vivo methods}

The second part of the experiment (in vivo) was conducted to assess the influence of copper ions on the body of laboratory animals and to determine the ability of probiotic strains to remove copper ions from the body of the laboratory animals. Five groups - two control groups and three experimental groups - were formed to conduct the study. The first control group received a basic diet $(\mathrm{K} 0)$, whereas the second group received a basic diet with copper sulfate $(150 \mathrm{mg} / \mathrm{kg}$ of body weight) (K2). The three experimental groups received a basic diet with copper sulfate and probiotics: Vetom-2 (O4), Sporobacterin (O5), and Bactisubtil (O6). Metal salts were administered on the $1^{\text {st }}$ day of the experiment, and the probiotics were administered from the $1^{\text {st }}$ day to the $7^{\text {th }}$ day. Biological materials were taken at a frequency of 7 days (the background study, on the $7^{\text {th }}, 14^{\text {th }}$, and $21^{\text {st }}$ days) by slaughtering the animals using the decollation method. In total, the duration of the experiment was 21 days.

The following methods were used in vivo: Measurement of biochemical blood indices, determination of the number of bacteria in the blood and feces of the laboratory animals, and the atomic-absorption method. The derived data were statistically analyzed using Student's t-test.

\section{Results}

The first phase included determining the MICs of copper ions on the growth of the Bacillus bacteria contained in probiotic preparations, which allowed us to obtain various concentrations of copper sulfate solutions from the initial $0.02 \mathrm{M}$. Obtaining several metal solution dilutions were necessary to determine 
the concentration that has a bactericidal and bacteriostatic effect on the studied microorganisms and concentrations that have no effect on their growth. This will create optimal conditions for cultivating the microorganisms in the presence of metal salt. From the obtained data, it appears that the most sensitive of the strains under study was $B$. cereus, which showed growth suppression at concentrations above 0.0001 $\mathrm{M}$. The remaining microorganisms had growth suppression at concentrations above $0.003 \mathrm{M}$. At the next stage, we evaluated the effects of copper ions on the growth of the microorganisms under study (Figure-1).

The presence of the excessive content of copper ions inhibits the activity of all microorganisms, and copper sulfate reduced the exponential growth phase by $6 \mathrm{~h}$ for $B$. licheniformis. The analysis of data on the bioaccumulating property of the probiotic strains under study (Figure-2) showed that B. cereus (part of "Bactisubtil") had the most pronounced sorbing effect at the accumulation level of $23.96 \%$. B. subtilis, which is part of the preparations Sporobacterin and Vetom2 , had close accumulation values of $10 \%$, which may indicate the species resistance of this microorganism. B. licheniformis (part of Vetom-2) had the lowest sorptive properties of all microorganisms under this study with an accumulation value of $6.7 \%$. B. licheniformis 7038 was selected for cell morphology analysis by atomic-strength microscopy. Some bacteria had irregularly shaped particles on the surface (Figure-3). Thus, these may be organic complexes with the metal formed by the release of biomolecules into the nutrient medium by cells. These observations characterize qualitative changes. Quantitative changes are represented in Table- 1 and indicate a decrease in the size of bacterial cells.

In the second part of the experiment, we studied the following parameters: The Bacillus bacterial count in the blood and feces of the laboratory animals (Figure-4), serum biochemical indices (Figures-4 and 5), and the bioaccumulating ability of the Bacillus bacteria under study (Tables-2 and 3). Based on the determination of the Bacillus bacteria count in the blood of the laboratory animals (Figure-5) relative to background values in $\mathrm{K} 2$ on the $14^{\text {th }}$ day, the

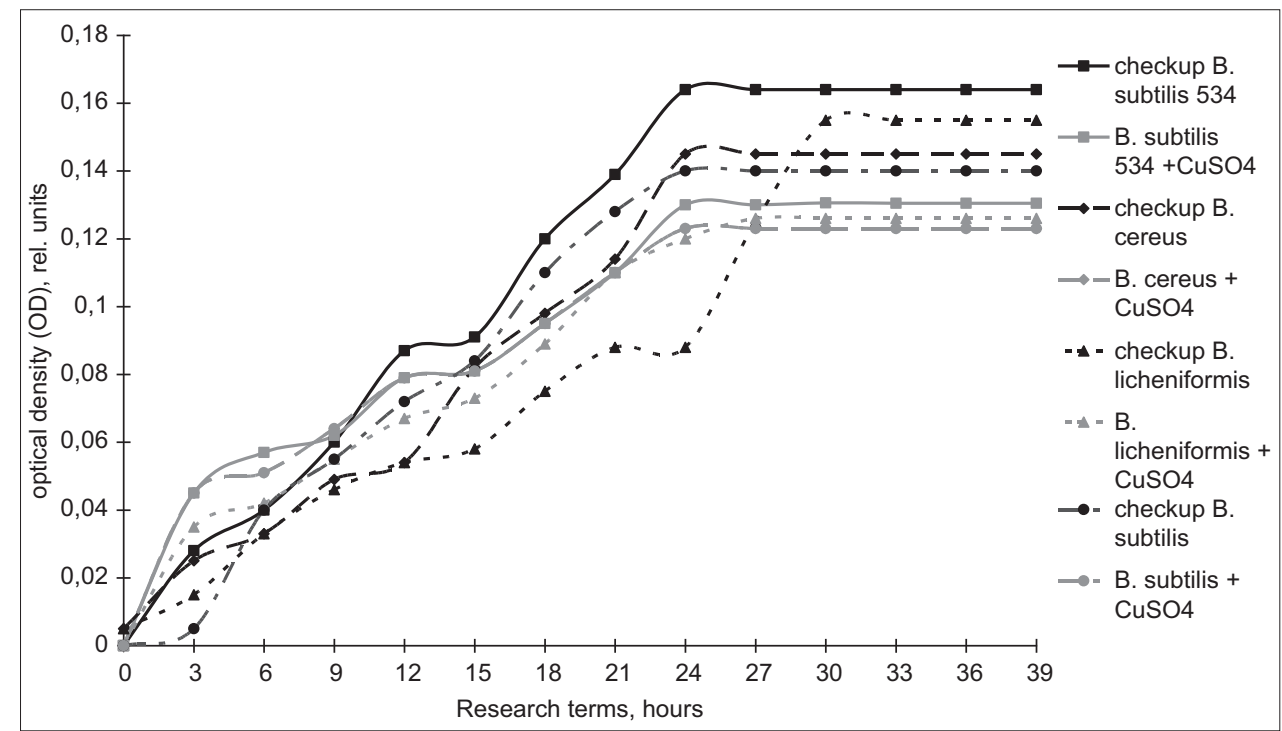

Figure-1: Evaluation of the impact of copper ions on the growth phases of the microorganisms.

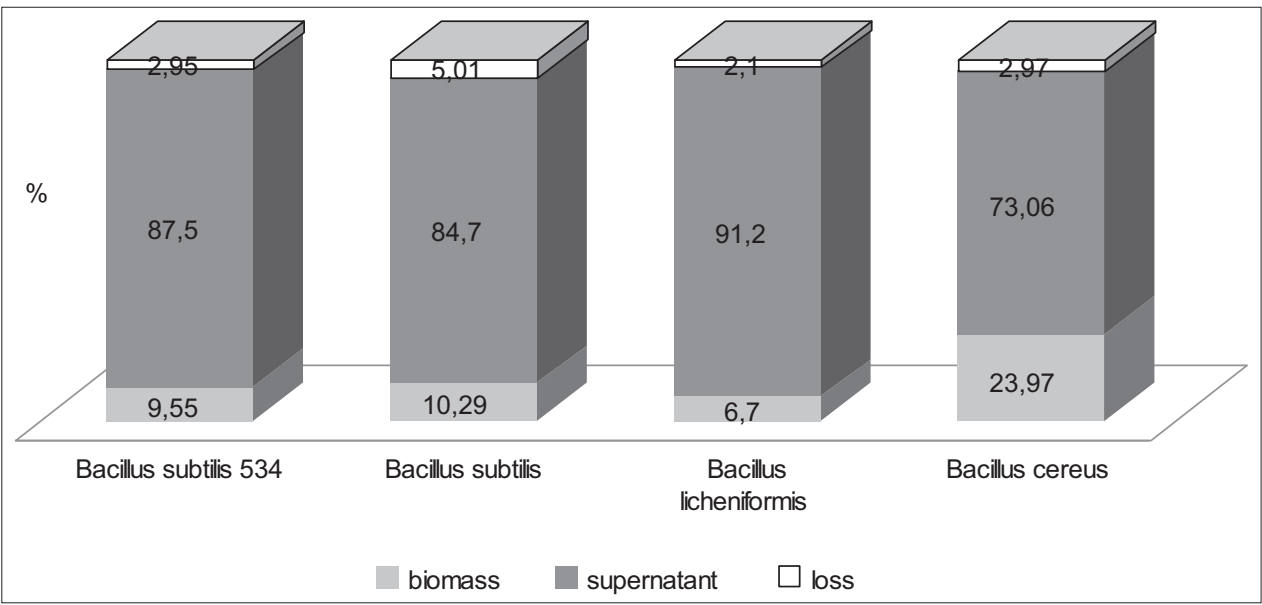

Figure-2: Evaluation of the bioaccumulating property of probiotic strains. 


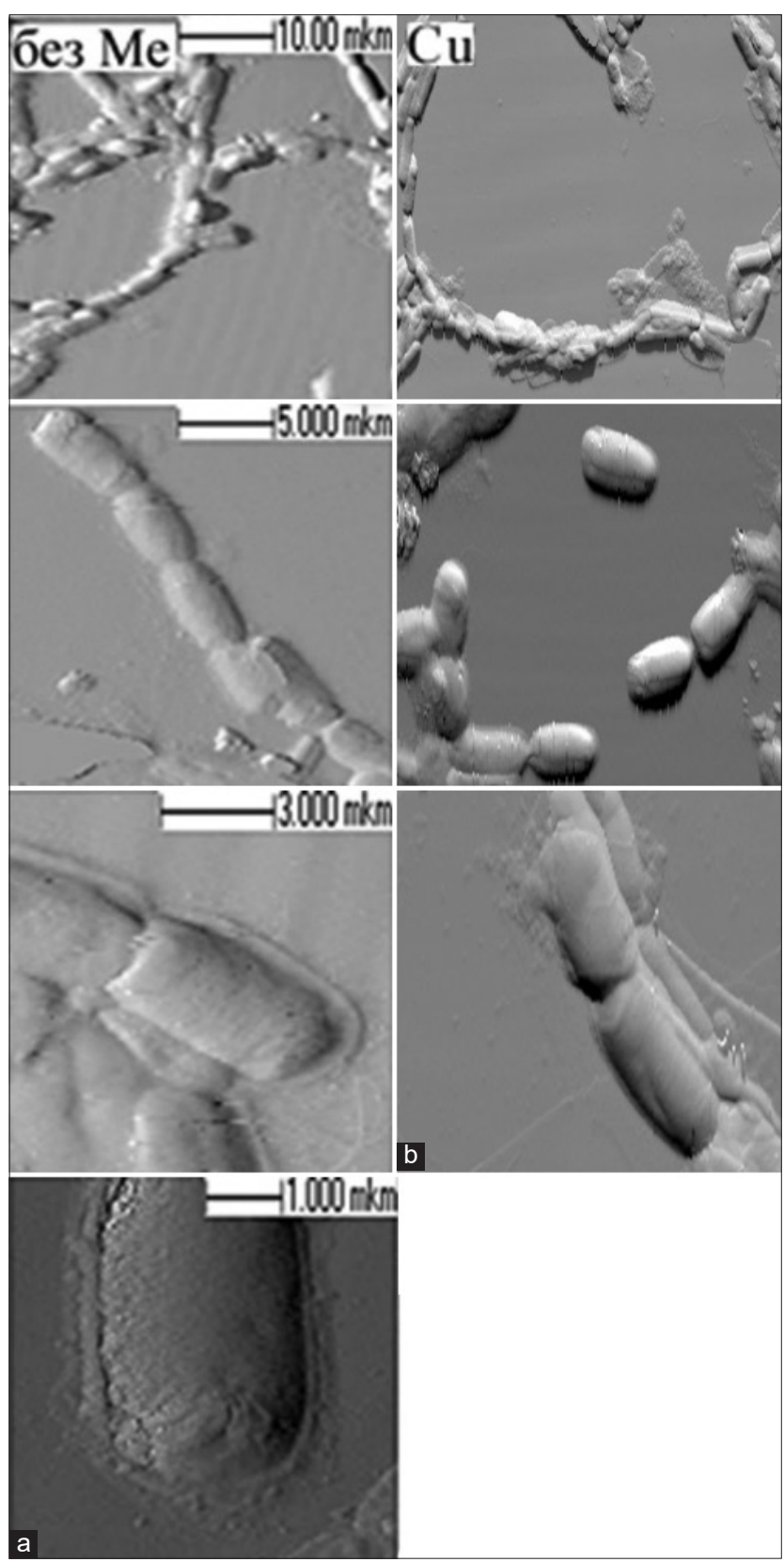

Figure-3: Images of Bacillus licheniformis 7038 bacteria derived using atomic-force microscopy: (a) No metals; (b) in the presence of copper salts.

Bacillus bacterial count was 2. Compared with background values, the three experimental groups showed an increase of $15 \%, 25 \%$, and $20 \%$, respectively, on the $7^{\text {th }}$ day, and an increase was observed on the $14^{\text {th }}$ and $21^{\text {st }}$ days of the study, whereas no increases in $\mathrm{K} 2$ and the overall control group were observed.

Figure-4 shows a change in the Bacillus bacterial count in the feces of the laboratory animals. Furthermore, in relation to background values on the $7^{\text {th }}$ day of the study, the experimental groups had an increase of $66.6 \%, 100 \%$, and $66.6 \%$ in Bacillus bacterial count. The effects of probiotic preparations and copper on biochemical blood indices (i.e. total bilirubin, alkaline phosphatase, alanine aminotransferase [ALT], and aspartate aminotransferase [AST]) throughout the study were examined. To visualize the

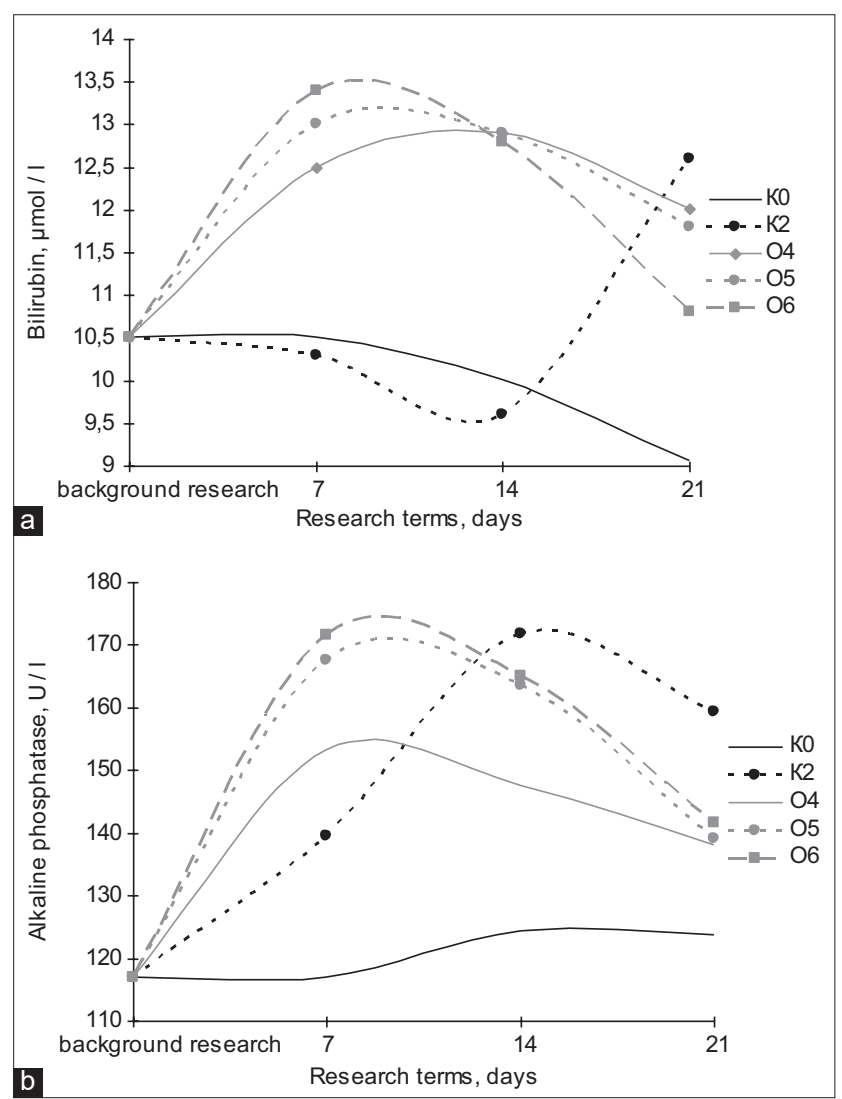

Figure-4: Dynamics of changes in the concentration of total (a) bilirubin and (b) alkaline phosphatase in laboratory animals: $\mathrm{K}_{0}$ - background, $\mathrm{K}_{2}$ - control of the metal $(\mathrm{Cu})$, $\mathrm{O}_{4}$ - "Vetom-2" and copper, $\mathrm{O}_{5}$ - "Sporobacterin" and copper, $\mathrm{O}_{6}$ - "Bactisubtil" and copper.

Table-1: Morphological characteristics of $B$. licheniformis 7038.

\begin{tabular}{lccc}
\hline & Length, $\boldsymbol{\mu m}$ & Width, $\boldsymbol{\mu m}$ & Height, $\mathbf{n m}$ \\
\hline $\mathrm{K}^{1}$ & $3.9 \pm 0.3$ & $2.2 \pm 0.1$ & $513 \pm 21$ \\
$\mathrm{Cu}$ & $3.3 \pm 0.7$ & $1.8 \pm 0.3^{*}$ & $653 \pm 104$ \\
\hline
\end{tabular}

${ }^{1} \mathrm{~K}$ - control without metal, $* \mathrm{p} \leq 0.01$

B. licheniformis=Bacillus licheniformis

data in dynamics, we built graphs for these biochemical indices. The analysis of the total bilirubin dynamics (Figure-6a) allowed us to generalize the overall dynamics of the experimental groups on the $7^{\text {th }}$ day of the study as the values of all three experimental groups were comparable, whereas the concentration of this index in $\mathrm{K} 2$ was below the level of the overall control group. On the $14^{\text {th }}$ day of the study, the total bilirubin values of the experimental groups varied widely with O4 having the highest value and O6 having the lowest value when $\mathrm{K} 2$ had the lowest values at this stage of the study. On the $21^{\text {st }}$ day of the study, O5 and O6 had a decrease in total bilirubin concentrations in the serum, but its concentrations in $\mathrm{O} 4$ and $\mathrm{O} 5$ were significantly higher than that of the overall control group; however, on the final stage of the study, the highest total bilirubin concentration was recorded in $\mathrm{K} 2$.

One of the criteria blood biochemical indices for treatment effectiveness is serum alkaline phosphatase 
Table-2: The significance of changes in the values of the experimental and control groups compared to $\mathrm{K}_{0}$ and $\mathrm{K}_{2}$ in the muscle and bone tissues, as well as the cutaneous covering, $(\mu \mathrm{g} / \mathrm{g})$.

\begin{tabular}{|c|c|c|c|c|}
\hline Group & Background & After 7 days & After 14 days & After 21 days \\
\hline \multicolumn{5}{|c|}{ The $\mathrm{Cu}$ content in the cutaneous covering } \\
\hline $\begin{array}{l}\mathrm{K}_{0} \\
\mathrm{~K}_{2} \\
\mathrm{O}_{4} \\
\mathrm{O}_{5} \\
\mathrm{O}_{6}\end{array}$ & $\begin{array}{c}0.26 \pm 0.05 \\
0.37 \pm 0.01 \\
.0 .28 \pm 0.08^{*} \\
\cdot 0.24 \pm 0.005^{*} \\
\cdot .0 .25 \pm 0.008^{*}\end{array}$ & $\begin{array}{c}0.230 \pm 0.003 \\
0.41 \pm 0.08 \\
\cdot 0.3 \pm 0.01^{* *} \\
\cdot 0.32 \pm 0.008^{* *} \\
\cdot 0.34 \pm 0.003^{*} * *\end{array}$ & $\begin{array}{c}0.22 \pm 0.05 \\
0.4 \pm 0.02 \\
\cdot 0.27 \pm 0.01 * \\
\cdot 0.27 \pm 0.01 * \\
\cdot 0.39 \pm 0.006 * * *\end{array}$ & $\begin{array}{c}0.22 \pm 0.03 \\
0.58 \pm 0.05 \\
\cdots 0.27 \pm 0.01^{*} \\
\cdots 0.24 \pm 0.005^{*} \\
\cdots 0.3 \pm 0.005^{*} \\
\end{array}$ \\
\hline \multicolumn{5}{|c|}{ The $\mathrm{Cu}$ content in the muscle tissue } \\
\hline $\begin{array}{l}\mathrm{K}_{0} \\
\mathrm{~K}_{2} \\
\mathrm{O}_{4} \\
\mathrm{O}_{5} \\
\mathrm{O}_{6} \\
\end{array}$ & $\begin{array}{c}0.24 \pm 0.01 \\
0.35 \pm 0.005 \\
\cdots 0.25 \pm 0.003^{*} \\
\cdots 0.23 \pm 0.008^{*} \\
\cdot 0.25 \pm 0.008^{*} \\
\end{array}$ & $\begin{array}{c}0.23 \pm 0.03 \\
0.4 \pm 0.01 \\
\cdot 0.46 \pm 0.008^{* *} \\
\cdot 0.35 \pm 0.008^{*} \\
\cdot 0.43 \pm 0.005^{*} \\
\end{array}$ & $\begin{array}{c}0.22 \pm 0.006 \\
0.45 \pm 0.01 \\
\cdot 0.37 \pm 0.003^{*} * * \\
\cdot \cdot 0.32 \pm 0.008^{* *} \\
\cdot 0.39 \pm 0.01^{* *}\end{array}$ & $\begin{array}{c}0.22 \pm 0.06 \\
0.48 \pm 0.008 \\
\cdots 0.34 \pm 0.006 * \\
\cdots 0.32 \pm 0.008^{*} \\
\cdots 0.37 \pm 0.003^{*} \\
\end{array}$ \\
\hline \multicolumn{5}{|c|}{ The $\mathrm{Cu}$ content in the bone tissue } \\
\hline $\begin{array}{l}\mathrm{K}_{0} \\
\mathrm{~K}_{2} \\
\mathrm{O}_{4} \\
\mathrm{O}_{5} \\
\mathrm{O}_{6}\end{array}$ & $\begin{array}{c}0.21 \pm 0.01 \\
0.23 \pm 0.01 \\
\cdot 0.2 \pm 0.01^{*} \\
\cdot 0.22 \pm 0.01^{*} \\
\cdot 0.2 \pm 0.008^{*}\end{array}$ & $\begin{array}{c}0.23 \pm 0.003 \\
0.58 \pm 0.01 \\
\cdots 0.38 \pm 0.008^{* * *} \\
\cdot 0.47 \pm 0.01^{* * *} \\
\cdot 0.44 \pm 0.03^{* *}\end{array}$ & $\begin{array}{c}0.22 \pm 0.01 \\
0.6 \pm 0.02 \\
\cdot 0.34 \pm 0.03^{*} \\
\cdot 0.45 \pm 0.006^{*} * * \\
\cdots 0.3 \pm 0.01^{* *}\end{array}$ & $\begin{array}{c}0.22 \pm 0.003 \\
0.64 \pm 0.01 \\
\cdots 0.31 \pm 0.008^{* *} \\
\cdots 0.44 \pm 0.01^{* * *} \\
\cdots 0.26 \pm 0.003^{* *}\end{array}$ \\
\hline
\end{tabular}

Table-3: Dynamics of copper removal with probiotic preparations in vivo (on the $21^{\text {st }}$ day of the experiment) and in vitro in \%.

\begin{tabular}{|c|c|c|c|c|}
\hline \multirow{2}{*}{$\begin{array}{l}\text { Probiotic } \\
\text { preparations }\end{array}$} & \multirow{2}{*}{$\begin{array}{l}\text { Biological } \\
\text { materials }\end{array}$} & \multicolumn{2}{|c|}{ in vivo } & \multirow[t]{2}{*}{ in vitro } \\
\hline & & $\begin{array}{l}\text { Removal } \\
\text { from } \\
\text { tissues }\end{array}$ & Mean & \\
\hline "Sporobacterin" & $\begin{array}{l}\text { Muscle tissue } \\
\text { Bone tissue } \\
\text { Cutaneous } \\
\text { covering }\end{array}$ & $\begin{array}{l}29.16 \\
51.56 \\
53.44\end{array}$ & 44.72 & 10.0 \\
\hline "Vetom-2" & $\begin{array}{l}\text { Muscle tissue } \\
\text { Bone tissue } \\
\text { Cutaneous } \\
\text { covering }\end{array}$ & $\begin{array}{l}33.33 \\
31.25 \\
48.52\end{array}$ & 37.7 & 16.7 \\
\hline "Bactisubtil" & $\begin{array}{l}\text { Muscle tissue } \\
\text { Bone tissue } \\
\text { Cutaneous } \\
\text { covering }\end{array}$ & $\begin{array}{l}53.75 \\
59.37 \\
58.27\end{array}$ & 57.13 & 23.96 \\
\hline
\end{tabular}

concentration (Figure-6b). The data presented in the graph show the effectiveness of probiotic preparations based on Bacillus bacteria in treating copper intoxication. On the $21^{\text {st }}$ day, the serum alkaline phosphatase concentration in all experimental groups decreased, and Sporobacterin (used in O5) appeared to be the most effective preparation because its values were the closest to K0 throughout the study. The dynamics of ALT concentration (Figure-6a) indicated that on the $7^{\text {th }}$ day of the study, all groups that received copper sulfate as the toxicant had significantly higher concentrations than the overall control with O6 having the highest ALT content and $\mathrm{O} 4$ having the lowest values. On the $14^{\text {th }}$ day of the study, the highest serum ALT concentration was observed in O5, whereas O6 had the lowest values. On the $21^{\text {st }}$ day of the study, O5 showed a decrease to the lowest values among the experimental groups; the ALT level in O4 slightly decreased compared with that reported in the previous study, but it should be noted that the metal intoxication control group recorded a sharp increase in ALT concentrations, far exceeding the indices not only of the overall control group but also of all control samples.

The analysis of serum AST concentrations of the experimental animals on the $7^{\text {th }}$ day of the study found that AST had higher values than that of the overall control group relative to group $\mathrm{K} 0$. On the $14^{\text {th }}$ day of the study, the difference in AST compared with K0 was $16.6 \%, 31.3 \%, 17.4 \%$, and $22.0 \%$ for $\mathrm{K} 2$, O4, O5, and O6, respectively. On the $21^{\text {st }}$ day of the study, even higher AST concentrations compared with $\mathrm{K} 0$ were observed: The difference was $8.21 \%, 9.04 \%, 2.19 \%$, and $3.56 \%$ for $\mathrm{K} 2, \mathrm{O} 4, \mathrm{O} 5$, and $\mathrm{O} 6$, respectively. In relation to the copper intoxication control group, all groups recorded values above those of the control group with differences of $0.75 \%, 5.5 \%$, and $4.3 \%$ for $\mathrm{O} 4, \mathrm{O} 5$, and $\mathrm{O} 6$, respectively.

Generalizing the data provides an opportunity to state the effectiveness of the use of probiotic preparations based on Bacillus bacteria in treating copper intoxication, as the main biochemical parameters allowing the evaluation of the metabolism processes related to detoxification, which include total bilirubin, ALT, and alkaline phosphatase, were lower than those of the copper intoxication control group on the $21^{\text {st }}$ day of the study, and the overall control group had minor deviations. The ability of Bacillus bacteria contained in probiotics to remove copper from the body was evaluated using the metal concentrations in the tissues of laboratory animals. The following biological materials were investigated for this purpose: Bone and muscle tissues and the cutaneous covering of the laboratory animals. Using atomic-absorption spectrophotometry, copper concentrations in the tissues under study (Table-2) were measured. 


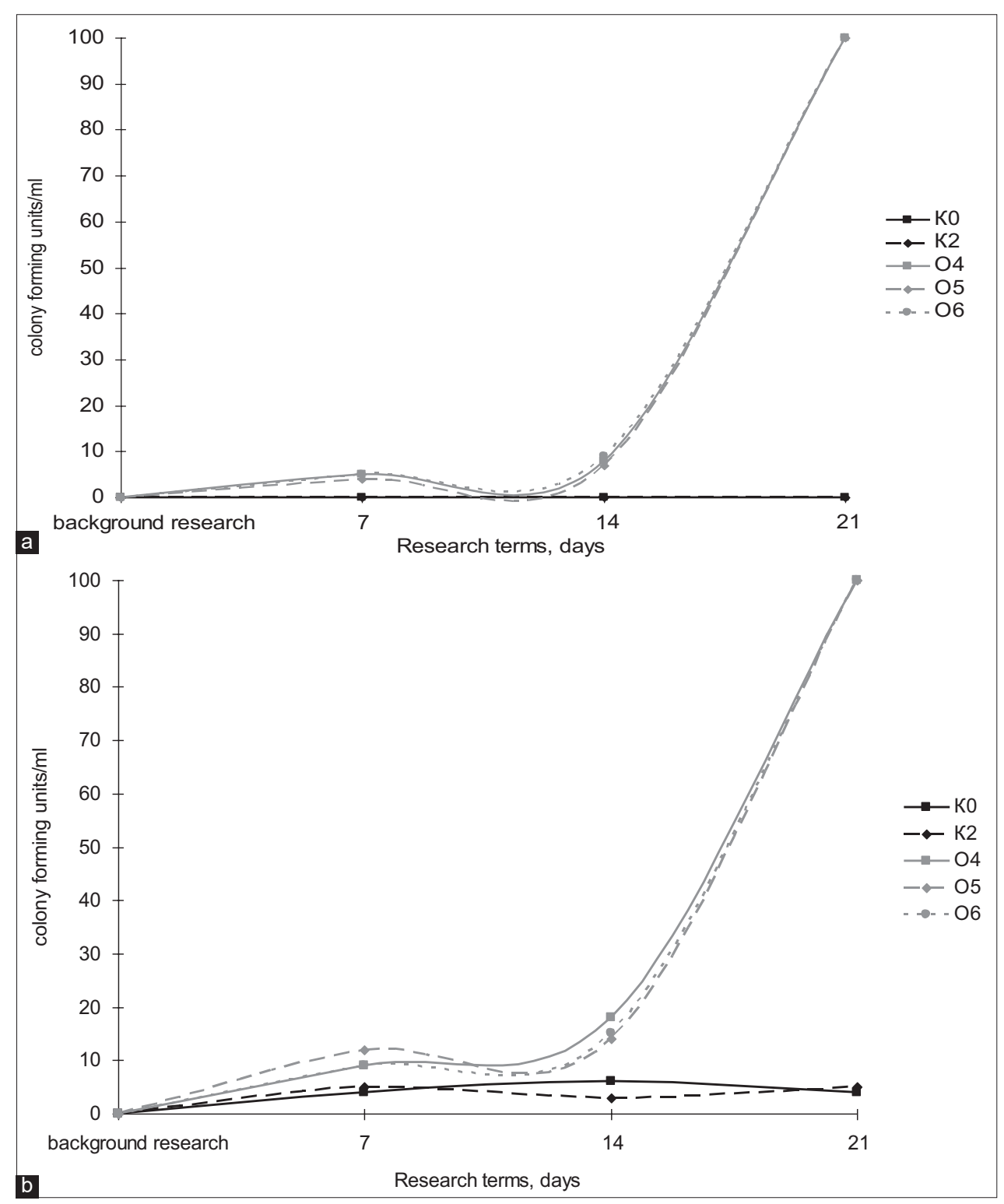

Figure-5: The total number of bacteria of the genus Bacillus in (a) blood and (b) feces of laboratory animals: $\mathrm{K}_{0}$ - background, $\mathrm{K}_{2}$ - control of the metal $(\mathrm{Cu}), \mathrm{O}_{4}$ - "Vetom-2" and copper, $\mathrm{O}_{5}$ - "Sporobacterin" and copper, $\mathrm{O}_{6}-$ "Bactisubtil" and copper.

The experiment found that the copper concentrations in the bone tissue of the laboratory animals on the $7^{\text {th }}$ day of the study in the experimental groups (i.e. O4, O5, and O6) exceeded those in $\mathrm{K} 0$ by $65 \%$, $99 \%$, and $91 \%$, respectively; however, the copper level in $\mathrm{K} 2$ was lower than that in $\mathrm{O} 4$ by $34 \%$, in O5 by $18 \%$, and in $\mathrm{O} 6$ by $24 \%$. Then, a steady decrease in the copper levels was observed on the $14^{\text {th }}$ and $21^{\text {st }}$ days of the experiment with the $14^{\text {th }}$-day values being below the $7^{\text {th }}$-day ones by $10 \%, 4 \%$, and $31 \%$ in $\mathrm{O} 4$, O5, and O6, respectively. These indices remained higher in K2; that is, $\mathrm{K} 2$ exceeded $\mathrm{O} 4$ (14 ${ }^{\text {th }}$ day) by $43 \%$, O5 by $25 \%$, and $\mathrm{O} 6$ by $50 \%$ on the $14^{\text {th }}$ day of the study.

On the $21^{\text {st }}$ day of the experiment, the copper contents were lower than those on the $14^{\text {th }}$ day by $8 \%, 2 \%$, and $13 \%$, respectively. Note that the copper levels in $\mathrm{K} 2$ were even higher than those in $\mathrm{O} 4$ by $51 \%$, O5 by $31 \%$, and O6 by $59 \%$ on the $21^{\text {st }}$ day of the experiment. The copper content in the muscle tissue of the laboratory animals on the $7^{\text {th }}$ day in the experimental groups (i.e. O4, O5, and O6) exceeded those in $\mathrm{K} 0$ by $99 \%, 52 \%$, and $86 \%$, respectively; however, the levels of the indices in the experimental groups were lower than those in K2 by $15 \%$ versus $\mathrm{O} 4$, by $12 \%$ versus $\mathrm{O} 5$, and by $7 \%$ versus $\mathrm{O} 6$. On the $14^{\text {th }}$ day, the copper levels in K2 decreased compared with those in the experimental groups on the $7^{\text {th }}$ day by $19 \%$ versus 04 , by $8 \%$ versus $\mathrm{O} 5$, and by $9 \%$ versus 06 , and therefore, the difference between the experimental groups and $\mathrm{K} 2$ increased by $2 \%, 16 \%$, and $6 \%$, respectively. Regarding the removal of copper from bone tissue on the $21^{\text {st }}$ day of the experiment, a decrease in copper levels removed from the muscle tissue was observed, and the copper content decreased in the experimental groups on the $21^{\text {st }}$ day of the experiment compared with those on the $14^{\text {th }}$ day by $8 \%, 1 \%$, and $5 \%$, respectively. On day 21 , 


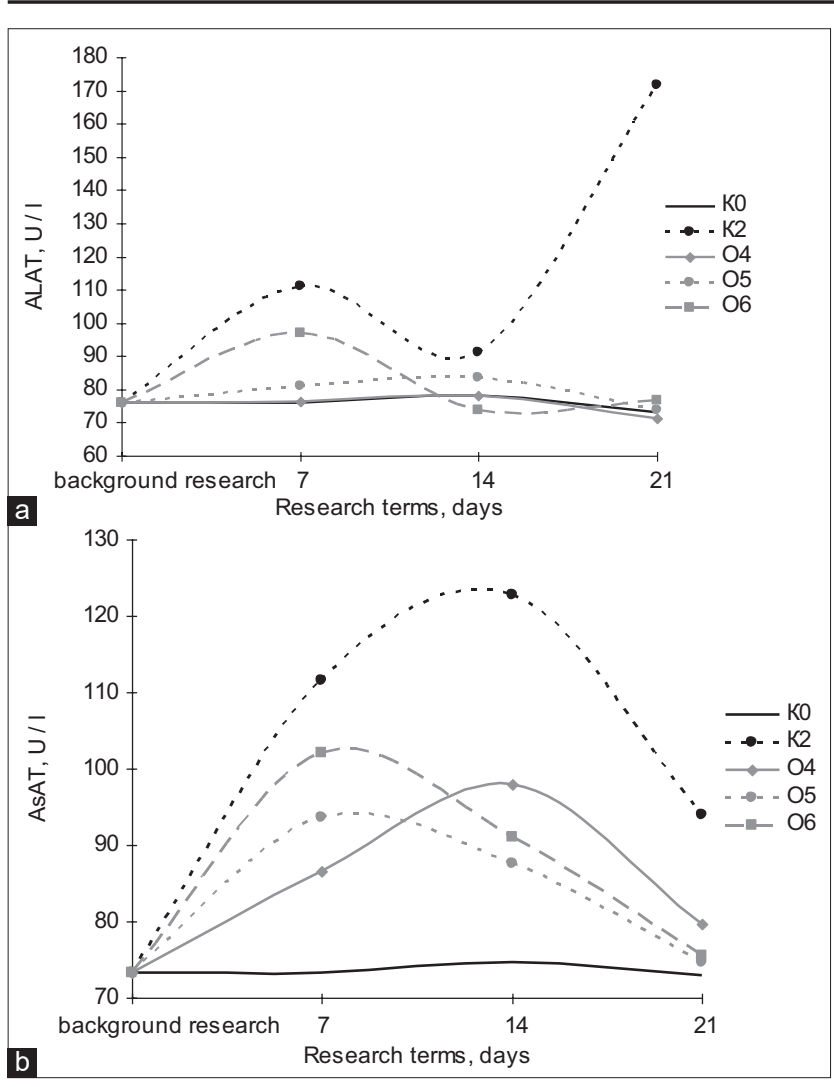

Figure-6: Dynamics of changes in the concentration of (a) ALT and (b) AST in laboratory animals: $K_{0}$ - background, $\mathrm{K}_{2}$ - control of the metal $(\mathrm{Cu}), \mathrm{O}_{4}$ - "Vetom-2" and copper, $\mathrm{O}_{5}$ - "Sporobacterin" and copper, $\mathrm{O}_{6}$ - "Bactisubtil" and copper.

the copper levels in $\mathrm{K} 2$ exceeded those in $\mathrm{O} 4$ by $29 \%$, $\mathrm{O} 5$ by $33 \%$, and $\mathrm{O} 6$ by $22 \%$.

The copper content in the cutaneous covering of the laboratory animals on the $7^{\text {th }}$ day of the experiment exceeded those in $\mathrm{K} 0$ by $30 \%$ in O4, by $39 \%$ in O5, and by $47 \%$ in $\mathrm{O} 6$, whereas these values remained lower than those in $\mathrm{K} 2$ by $27 \%, 22 \%$, and $17 \%$, respectively. The values in the experimental groups on the $14^{\text {th }}$ day of the experiment were lower than those on the $7^{\text {th }}$ day by $10 \%$, $15 \%$, and $14 \%$, respectively, and the difference between $\mathrm{K} 2$ and the experimental groups increased by $5 \%, 10 \%$, and $3 \%$, respectively. On the $21^{\text {st }}$ day of the experiment, a reduction in the copper removal was observed; the $21^{\text {st }}$-day values in the experimental groups differed from $14^{\text {th }}$-day ones by $1 \%$ for O4, by $10 \%$ for O5, and by $20 \%$ for O6. On the $21^{\text {st }}$ day of the experiment, the values in $\mathrm{K} 2$ were higher than those in the experimental groups by $53 \%, 59 \%$, and $48 \%$, respectively.

The results are not in complete accordance with the results derived from the in vitro experiment where the least active biosorbent was Sporobacterin, whereas in vivo, it was Vetom-2 (Table-3). However, both experiments proved that $B$. cereus 5832 , which is part of Bactisubtil, was a more active biosorbent.

\section{Discussion}

In the previous studies, we found pronounced sorption characteristics of representatives of both the intestinal microbiome and probiotic strains based on them. In this study, we have studied the prospects of using physiological and adaptive mechanisms of resistance of transient probiotic strains in the system of correction of the elemental status of the animal body due to excessive copper intake. The advantage of their use is due to not only sorption but also the high level of elimination of complexes accumulated on the surface. The use of the biological potential of representatives of the microbiome and transient symbiotic flora is essential to the scientific community in various fields of human activity. Along with the classical idea of the physiological significance of probiotic strains in the processes of human and animal life, some studies have aimed at studying alternative ways to use the antagonistic and physiological-adaptive characteristics of bacterial strains [11-13]. Considering the updated data, updated ideas are formed about the participation of representatives of the microbiome and probiotic strains, particularly in physiologically significant processes [14-16].

The generalized analysis of experimental data allows us to state, with a high level of confidence, the presence of mechanisms of sorption of active copper cations by the strains under study, which is consistent with the previously published data on the presence of sorbing characteristics of Bacillus bacteria with respect to heavy metals [17]. The high level of biotoxicity of copper cations relative to the microorganisms under this study and laboratory animals in relatively high concentrations may be due to the lack of detoxification mechanisms of protection against essential elements [18]. This explains the relatively low level of cation sorption in in vitro experiments and the presence of high cation load reduction characteristics in the tissues of the experimental animals. The advantage of using probiotic strains based on Bacillus bacteria is their ability to sorb excessive concentrations of active metal cations not only in the intestinal lumen but also in the body tissues, reducing the degree of hepatotoxic effect, which is confirmed by the results of the biochemical study of the blood of the experimental animals [19-21].

\section{Conclusion}

This study was conducted to examine the effectiveness of probiotic preparations based on spore-forming Bacillus bacteria in the experimental intoxication of laboratory animals with copper. In this study, we found that probiotic preparations based on spore-forming Bacillus bacteria do not affect biochemical indices of blood and biotissues (i.e. the muscle and bone tissue and the cutaneous covering). In addition, the preparations contribute to reducing the toxic effects of copper ions on the body. Thus, the cutaneous covering has the greatest accumulation property relative to copper ions. The most effective probiotic under this study in copper ion poisoning was Bactisubtil, whereas the least effective one was Vetom-2. 


\section{Authors' Contributions}

AS, ES, and YS: Designed the experiment. SP and EB: Performed the experimentation. ON and NR: Wrote and edited the manuscript. All authors have read and approved the final manuscript.

\section{Acknowledgments}

The authors are quite thankful to their ideological inspirer, professor D.G. Deryabin and senior research scientist O.V. Kvan for help in the study. The authors did not receive any funds for this study.

\section{Competing Interests} interests.

The authors declare that they have no competing

\section{Publisher's Note}

Veterinary World remains neutral with regard to jurisdictional claims in published institutional affiliation.

\section{References}

1. Kalmykova, A.I. (2003) Probiotics: Therapy and Disease Prevention. Improving Health. SibNIPTIP SO RASKhN, Novosibirsk.

2. Boyle, R.J., Robins-Browne, R.M. and Tang, M. (2006) Probiotic use in clinical practice: What are the risks? Am. J. Clin. Nutr., 83(6): 1256-1264.

3. Zaprudnov, A.M. and Mazankova, L.N. (2008) Microbial Flora of the Intestine and Probiotics. MSU, Moscow. p32.

4. Babenko, G.A. (1998) The Biological Role of Copper. Nauka, Moscow. p239.

5. Pan, K. and Wang, W.X. (2009) Biodynamics to explain the difference of copper body concentrations in five marine bivalve species. Environ. Sci. Technol., 43(6): 2137-2143.

6. Zyadah, M.A. and Abdel-Baky, T.E. (2000) Toxicity and bioaccumulation of copper, zinc, and cadmium in some aquatic organisms. Bull. Environ. Contam. Toxicol., 64(5): 740-747.

7. Khanturina, G.R., Ibraeva, L.K. and Nortseva, M.A. (2011) Cytogenetic disorders in intoxication with zinc and copper salts. Sovrem. Naukoemkie Tekhnologii, 3(1): 13-15.
8. Montes, D. (2006) Removal of mercury (II) from aqueous solutions of non-viable cells of Bacillus. Biotechnology, 97(7): 1907-1911.

9. Zolotov, Y.A. (1996) Basics of Analytical Chemistry. Khimiya, Moscow. p199-262.

10. Britzke, E.M. (1982) Atomic Absorption Spectral Analysis. Khimiya, Moscow. p224.

11. Meurman, J.H. and Stamatova, I.V. (2018) Probiotics: Evidence of oral health implications. Folia Med., 60(1): 21-29.

12. Nair, S.S. and Prajapati, J.B. (2018) Probiotics: A novel natural therapy for oral health. Int. J. Probiotics Prebiotics, 13(1): 1-10.

13. Escandón, C.L.A. and Ramírez, J.M.C. (2018) Dentistry facing the biotechnological advances of the $21^{\text {st }}$ century. $J$. Oral Res., 7(7): 216-218

14. Alp, S. and Baka, Z.M. (2018) Effects of probiotics on salivary Streptococcus mutans and Lactobacillus levels in orthodontic patients. Am. J. Orthod. Dentofacial. Orthop., 154(4): 517-523.

15. Theodorou, V. (2018) Probiotics, stress, and irritable bowel syndrome. Phytothérapie, 16(6): 320-325.

16. Nishihira, J. (2019) The role of probiotics in sports: Application of probiotics to endurance exercise. In: Nutrition and Enhanced Sports Performance. Academic Press, United States. p423-428.

17. Floch, M.H., Walker, W.A., sanders, M.E., Niewdorp, M., Kim, A.S., Brenner, D.A. and Dieleman, L.A. (2015) Recommendations for probiotic use-2015 update: Proceedings and consensus opinion. J. Clin. Gastroenterol., 49(1): S69-S73.

18. Umbrello, G. and Esposito, S. (2016) Microbiota and neurologic diseases: Potential effects of probiotics. J. Transl. Med., 14(1): 298.

19. Sizentsov, A.N., Kvan, O.V., Sizentsov, Y.A., Bibartseva, E.V. and Osipova, E.A. (2019) Comparative analysis of heavy metal sorption characteristics on laboratory animal models. Res. J. Pharm. Biol. Chem. Sci., 10(1): 1313-1316.

20. Sizentsov, A.N., Cherkasov, S.V., Karpova, G.V., Bibartseva, E.V., Kvan, O.V., Kunavina, E.A., Levenets, T.V. and Strekalovskaya, A.D. (2018) The technology of chemical compound biotoxicity assessment by the method of agar basins. Int. J. Mech. Eng. Technol., 9(11): 455-446.

21. Peshkov, S.A., Sizentsov, A.N., Nikiyan, H.N. and Kobzev, G.I. (2015) Study on the bioaccumulation of heavy metals by bacteria of the genus Bacillus. using XRF analysis and atomic force microscopy. Mod. Probl. Sci. Educ., 4(1): $1-7$.

\section{$* * * * * * * *$}

